\title{
3. \\ Dancing from Te Kore into Te Ao Marama
}

\author{
CATHY LIVERMORE
}

\begin{abstract}
Contemporary Indigenous performance awakens and brings into 'now' the inherited mauri of all that we are, carried through the wairua from our ancestors and the whenua in the woven whariki of memory held in time and space. Whether in Aotearoa or on another's whenua, on a stage, in someone's lounge room or in the ngahere gathering rongoa, when we dance from te kore into te ao marama, we activate ihi, wehi and wana: a power that awakens within and between us and the universe. We come alive in the performance of our cultures and ourselves, see our living relevance today, and are uplifted by our potential to contribute to our world socially, culturally, politically, spiritually and personally. Māori culture activates in me keys and the tools, ways of moving and giving voice, the power to share who I am in my fullness today with other cultures. This presentation reflects on the power of my own current practice as it represents the culmination of my performances, dance teaching, cultural exchanges and facilitation experiences within New Zealand and internationally. How might performing as Maori and Indigenous peoples be seen to strengthen and empower our selves, communities and cultures, whoever and wherever we are in the creation of the future?
\end{abstract}




\section{Introduction}

The living world of contemporary indigenous 'being' is a dynamic, morphing space of remembering and becoming at the same time. It is a complex experience that is, at the same time, threaded with simplicity and caught in notions of resounding conscious wisdom. At the end of the day, each of us has our own version of how everything weaves together. To tune you into my frequency, I'd like to drop you into my paper by first introducing you to some core beliefs that have grown into being mine from the experiences I have had over the many blessed years sharing and exchanging performance, culture, land, relationships and experiences in ceremony and daily life around the world. These three core beliefs, you could say, have been shown to me to be true through living them, and I give deep thanks for their gifted teachings.

\section{Firstly,}

Activation of indigenous consciousness is a living process that awakens our cellular DNA and aligns us with all the memories of this universe, which is all that we are: each of us literally seeded from the very beginning of the universe stirring and its growing and manifesting of everything till this moment, and all that we have and are in this moment that we carry dreaming into the possibilities of future.

\section{Secondly,}

Activation through indigenous cultures also aligns us with specific vibrational codes of planetary and human memory and experience of the relational forces that have been in creative conversation in this universe over eons. These memories are living frequencies of consciousness that affect and create. They are a dynamic force that has been reflected over and sculpted through generations into refined wisdom and knowing from 
evidence gathered over many generations, they are what we term 'culture'.

\section{And thirdly,}

The potential to activate and awaken to these frequencies, or states of consciousness, is innate in indigenous dance and song. Contemporary indigenous performance re-activates these frequencies and brings into 'now' the inherited mauri of a culture's evolving and manifesting consciousness, carried through the wairua from our ancestors and the whenua in the woven whariki of memory held in time and space.

\section{To sing and dance is to honour this creation, our shared universe.}

Within our creation stories, as Māori, we have many teachings and insights into the purpose and the science of this universe's forces in action. For me, the creation story of Ngā Puhi gives great insight into the complex layers of dynamic living forces that brought about this physical world we are blessed with and which our tikanga is designed to engage and direct in creative collaboration with the universe itself.

All begins with AIO, the universal creative life force from which all things have been birthed. From stillness movement was manifested and the dance began as AIO manifested the possibility of life through IO and continued to transform in cycles of rebirth and incarnation many times rolling toward Te Kore and the state of sacred potential and emptiness.

From this still, empty space of sacred potential and emptiness was birthed the energy of life, its pulsing unconscious desire and purpose 
expanding out of Te Kore the potential to birth the creation of Te Ao Marama . . . .

With this desire and purpose was born Te Hihiri the spark of life force that energises and charges all possibility in this universe and gives life ....

From which births imagination and dreaming possibility from the unknown and subconscious/Te Mahara....

Which expands and grows, and in its expansion begins stretching and carving pathways of memory recollecting and repeating starting to dance in infinite directions birthing consciousness out of the unknown/Te Hinengaro . . . .

From which is birthed the possibility for the sharing of inspiration and exchange in collectives of new possibilities directing consciously the force of intention/ Te Wananga .... .

From which is birthed experience, reflection and knowing/Te Whakaaro.

From the oscillating interplay of these potent spaces the force of sound is created /vibration and frequency/intention and the force of thought, sending waves of potential through the universe/ Te Whe ....

And as these waves start to travel and dance shape and form become possible, filled and sculpted by all that has come before/ Te Ahua and Te Atamai arise .... 
As these shapes and forms start to dance they create relationships that births time and space/Te Wa and Te Atea ....

And with Te Hau Ora gifted the physical world becomes possible as Ranginui and Papatuanuku were born, giving birth to the elemental possibilities for creating life ... . Te Ao Marama was actualized.

I love this expression of creation. It brings this universal process of coming into being alive, giving a visceral sense of the dynamic process of creation. I can feel the dance of it in my cells and see it in my mind's eye.

\section{AIO and the universal kaupapa - The gift of the relational}

From the stirrings within the universal womb of AIO, the deep inner spaces, journeying outward, IO manifesting expansive possibility growing into the outer spaces we are gifted the universal duality that births. Through the duality is created the relational consciousness that is the fabric of how this universe dynamically creates itself: inner and outer, still and expansive, potential and manifestation and the sacred masculine and feminine forces enabling the birthing of all possibilities of life.

The acknowledgement of this 'relational' perogative and norm for how our universe functions and sustains itself underpins Te Ao Māori and the tikanga that nourishes this living cultural consciousness. Cultivating one's own and the collective's attentiveness and sensitivity of skill in tending to relational dynamics as a priority of 'being' or 'living' can be seen as the very foundation from which our cultural worldview and practices have grown and developed. But how can or do we tend to these relational spaces? How do we enact our priorities and have an effect on the universe?

Te Kaharoa, Special Edition, Ka Haka - Empowering Performance: Māori and Indigenous Performance Studies Symposium, vol. 9, 2016, 
If we return again to our creation story, we see that it is first movement, as stirrings, and then sound, created through the building of consciousness birthing sound/Te Whe, that has been the active forces creatively manipulating, affecting, manifesting and transforming the universe. While the universal purpose is birth and creation made possible through the dynamics of relational possibility, we are told by our ancestors that the universal tools or forces for manifesting and transforming potential life force into new possibility is movement and sound.

Movement and sound are the raw, original states of energetic potencies and active forces that invigorate and enliven the live dynamic energies of the relational spaces from which new creative possibilities are created and birthed. Movement and sound are the active potent forces that enable and connect all creation and its growth. They are the active science of how we came to be. Maybe this is why, though as humans we have evolved in different climates and landscapes, isolated from other peoples, yet still we have all evolved with this in common: we sing and we dance?

Furthermore our songs and dances are active ways we connect, engage with and tend to relational spaces in our rituals, ceremonies and protocols. Our songs and dances are also connecting activators carrying and awakening our shared human memory and histories into the present. Our songs and dances also give us tools to connect ourselves to these memories while we actively participate in creating the future - what we keep alive and relevant in consciousness and through the new possibilities we bring into expression. We harness, direct, transmit, translate, express, transform and celebrate life when we sing and dance. We have inherited the tools we can and do use for facilitating the actualizing of new possibility into being in Te Ao Māori through movements and sounds cultivated into dance, language and song.

This is what I call dancing from Te Kore into Te Ao Marama.When we dance, we activate ihi, wehi and wana: a 
power that awakens within and between us and the universe. These are the dynamic forces within the relational space that I referred to earlier: ihi being the activated potential force within self and wehi, the activated potential force of another meeting in the wa and creating the wana. Through the relational these three activations are created, and from the two, ihi and wehi in relationship, is birthed the new possibility within the wana. Here again is our universal kaupapa confirmed where new creative possibility is birthed from the relational forces activated in their potential. It is the exchange and sharing of the mauri within the ihi and wehi that activates and actively acknowledges the relational space.

While what we are working with is the living science as laid out for us in our creation stories, the purpose of our song and dance can be seen as an act and a process of acknowledging and giving expression to all and each of that we are in relationship with: be it in the physical world of people, animals or nature or of the wairua with tupuna, Atua and other entities. Through the living energy we activate and exchange in singing and dancing; we invigorate and energise the relationships we have received and experienced from life - good and not so good - from the place of who and what we are in that moment. In using our sound and movement we repeat and remember and continue participating in that which we have come from.

When we do this we activate the force of ourselves, our ihi, which enlivens all that we are and connected to: Whakapapa, Mana and Aroha. And the universe hears us and recognizes and remembers with us, and we are in that moment complete and transcended from Noa into Tapu.

When we sing and dance we can also add something more, further imbuing our sound and movement with ourselves, with simply our full, willing, generous, listening, joyful presence. It is this consciously added element of ourselves that enables us to return the gift of all that we are and give something of ourselves back into all that we have come from. In this we 
complete the eternal circle that allows the universe to keep creating through the exchange of mauri.

Singing and dancing is our way of reflecting and giving back, activating and nourishing the exchange of mauri and wairua. When we do so in such a way that we invigorate and expand and charge our energy field and vibration, we transform the possible 'now' and ourselves into a greater potential creative force. This is the living science, the physics of what we do and are. The social and human aspect of this science can be described as 'being empowered' - where new things are possible and we are open and expanded into those possibilities and confident in being present to them and creating with these possibilities as individuals, families, communities and cultures. Whether in Aotearoa or on another's whenua, on a stage or in someone's lounge room or in the ngahere gathering rongoa, we bring the universal memories we carry, which are us, alive in the performance of our cultures and ourselves, see our living relevance today, and are uplifted by our potential to contribute to our world socially, culturally, politically, spiritually and personally.

Being of the sacred empty state of Te Kore through the leaping spark of energy, Te Hihiri, through dreaming of $\mathrm{Te}$ Mahara and into collective conscious intention through $\mathrm{Te}$ Hinengaro, Te Wananga and Te Whaakaro to travel out through Te Whe and through shape and form Te Atamai/Te Ahua create time and space, Te Wa/Te Atea, to bring out into Te Ao Marama it is movement and sound, dance and song, that have made possible all that we are and all that will be: of this universe; life in creation, creation in life; Cathy Livermore, human being living within planet Earth. 
Cathy Livermore (Waitaha, Kati Mamoe, Kai Tahu) is a dancer, choreographer, teacher and healer. She is an independent artist and Head of Dance at PIPA (Pacific Institute of Performing Arts). In 2014, Cathy was invited to participate in New Mexico, USA, with Dancing Earth's Summer Intensive Residency where she performed, choreographed and taught with an international delegation of twenty-five indigenous artists. In 2015, Cathy initiated and co-ordinated Taharangi, a three-staged international indigenous choreographic research and collaboration facilitated within three diverse communities in $\mathrm{NZ}$, including Auckland, Taranaki and Dunedin, involving community development, choreographic development and performance funded by $\mathrm{CNZ}$ whilst hosting international indigenous artist Trey Pickett for three months of cultural and artistic wananga. Cathy's most recent work 'Wai me' was performed as part of Pacific Skin, multimedia interactive technology dance performance in April 2015, as part of an international collaboration with Japanese dance artists. Cathy was selected by CNZ in its Asia Artist Exchange Fund and travelled to Japan for a cultural exchange and a creative choreographic research process in collaboration with Japanese dance artist, Aska Suzuki, engaging with three different communities within Japan: the indigenous people of northern Japan, the Ainu, with the religious community of Shinto and with the professional and youth dance communities of urban Nagoya. 